\title{
The challenges of a small population exposed to multiple anthropogenic stressors and a changing climate: the St. Lawrence Estuary beluga
}

\author{
Véronique Lesage \\ Fisheries and Oceans Canada, Maurice Lamontagne Institute, Mont-Joli, QC, Canada
}

\begin{abstract}
Until 2012, the St. Lawrence Estuary beluga population was considered stable with about 1100 individuals. An abnormally high number of calves reported dead that year triggered a population status reassessment. This review article summarizes the findings from this reassessment and various studies subsequent to it and provides an updated analysis of carcass recovery rates up to 2019. The 2013 review indicated a decreased incidence of cancer in adults, suggesting positive impacts from the regulation of toxic substances (e.g., PCBs and PAHs). However, the review also revealed that the population initiated a decline of ca. $1 \%$ per year in the early 2000s and had reached a size of ca. 900 individuals by 2012. This decline was accompanied by high inter-annual variability in calf survival and pregnancy rates and by more frequent peripartum complications among dead females. The change in population dynamics coincided with a shift in the St. Lawrence ecosystem structure and warmer environmental conditions, suggesting a link through effects on reproductive success and adult female body condition. This was supported by the continued high calf mortality after 2012 and a documented decline of fat reserves in beluga blubber from 1998 to 2016. Other factors, such as the exposure to chronic vessel noise, increasing whale-watching activities, high contaminant levels and episodic harmful algal blooms, may also be contributing to the long-term non-recovery and current decline of the population. The strong natal philopatry and complex social system of the beluga likely increase its vulnerability to extinction risk by limiting dispersal.
\end{abstract}

This article is part of the special cluster Beluga whales (Delphinapterus leucas): knowledge from the wild, human care and TEK, which has been funded by Mystic Aquarium, CAFF and the Norwegian Ministry of Climate and Environment.

\section{Keywords}

Delphinapterus leucas; climate change; population dynamics; noise; food availability; cumulative effects

\section{Correspondence}

Véronique Lesage, Fisheries and Oceans Canada, Maurice Lamontagne Institute, Box 1000,850 route de la Mer, Mont-Joli, QC, G5H 3Z4, Canada. E-mail veronique.lesage@ dfo-mpo.gc.ca

\author{
Abbreviations \\ AIC: Akaike information criterion \\ $\mathrm{Cl}$ : confidence interval \\ COSEWIC: Committee on the Status of \\ Endangered Wildlife in Canada \\ DDT: dichlorodiphenyltrichloroethane \\ DFO: Fisheries and Oceans Canada \\ NAFO: North Atlantic Fisheries Organization \\ PAH: polycyclic aromatic hydrocarbon \\ PBDE: polybrominated diphenyl ether \\ PCB: polychlorinated biphenyl \\ POP: persistent organic pollutant \\ SLE: St. Lawrence Estuary
}

\section{Historical context}

The beluga (Dephinapterus leucas) has a discontinuous circumpolar distribution in the Arctic and Subarctic regions, with eight populations occurring in Canadian waters (Stewart \& Stewart 1989; COSEWIC 2016). The lack of a dorsal fin and a relatively thick dermis (5-12 mm) make the species particularly well adapted to environments with seasonal and extensive ice cover. The population in the SLE, Canada, is at the southern limit of the species' global distribution and probably established itself thereafter the Wisconsin glaciation (Harington 1977, 2008). The beluga persistence in the SLE is probably largely due to the combination of an extensive and seasonal seaice cover and the cold and productive environmental conditions that are maintained in this region in part from the influx and upwelling of Arctic waters of the Labrador Current (El-Sabh \& Silverberg 1990).

The SLE beluga, like several other populations, undertakes seasonal movements, but its extent appears limited to a few tens or hundreds of kilometres (Mosnier et al. 2010). The core of its distribution remains in the SLE year-round, but an unknown and likely variable proportion of the population moves eastward each fall to winter in the western Gulf of St. Lawrence (Fig. 1). While immigration from other populations might have been notable a century ago (Vladykov 1944), the SLE beluga population now has the lowest haplotype diversity of all beluga populations and shares none with other populations (Postma 2017; Skovring et al. 2019). 


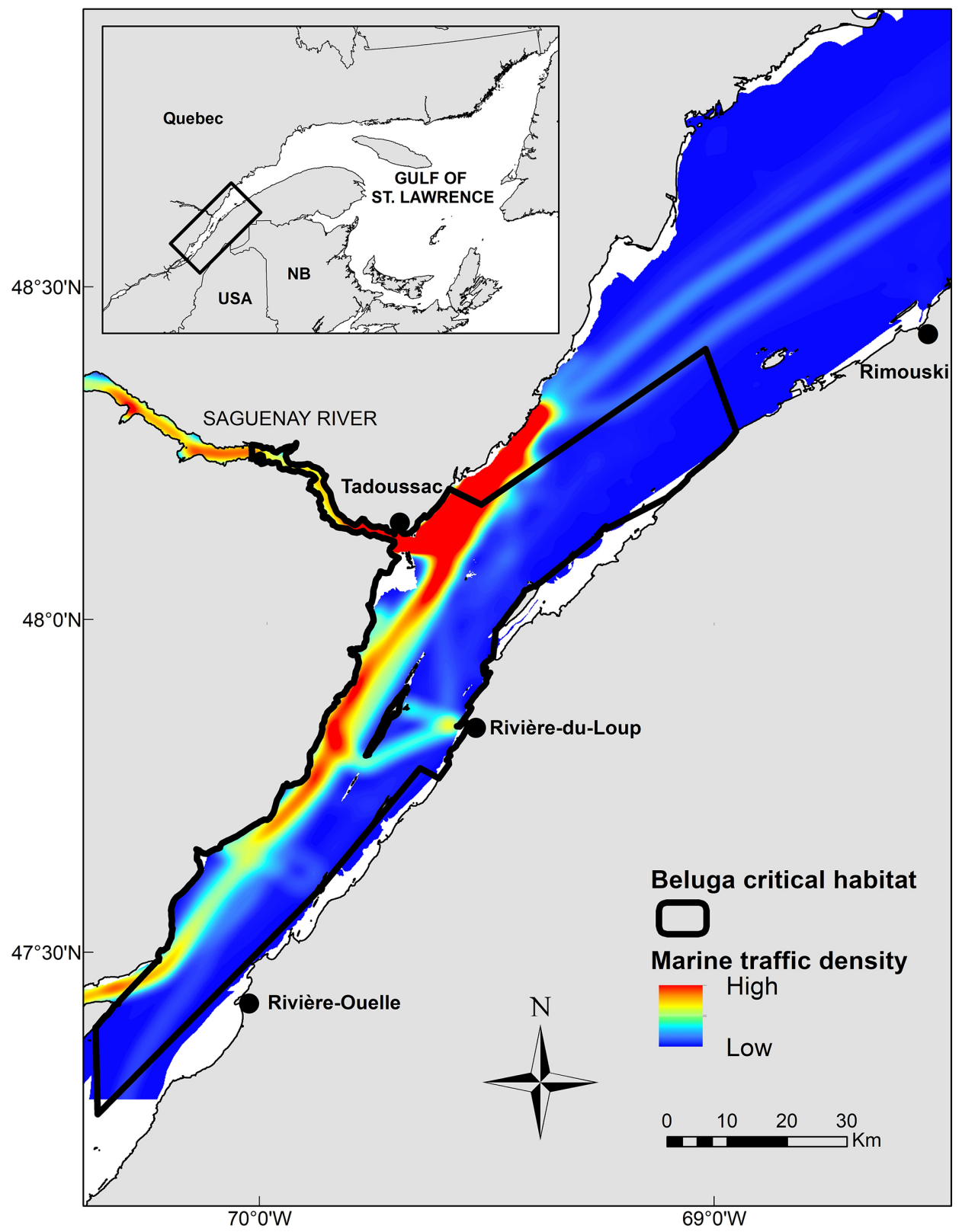

Fig. 1 Relative density of marine traffic in the summer range of SLE beluga and their designated critical habitat. Traffic includes merchant ships, ferries and some of the whale-watching vessels equipped with automatic identification systems. Recreational vessels and two ferries operating downstream of the Saguenay River and connecting the north and south shores are not included. White areas indicate areas with no traffic. Adapted from Chion et al. (2009)

Their nuclear genetic diversity is similar to insular populations of mammals (Patenaude et al. 1994), suggesting insignificant contributions from neighbouring populations and a distinctly isolated population (Postma 2017).

The SLE beluga population declined from a pristine size estimated at about 8000 individuals in 1866 to a few hundreds of individuals at the end of the 1970s as a result of hunt and bounty programmes that thrived from the 1500s to the mid-1900s (Vladykov 1944; Reeves \& Mitchel 1984; Hammill et al. 2007). Interest in the fate of this population progressively rose with governments and the public, leading to a complete halt of the hunt in 1979 and the population designation as Endangered in 1983 by the Committee on the Status of Endangered Wildlife in Canada (Pippard 1985). There were concerns at the time about high contamination of sediments and 
habitat loss from the development of a marina in Tadoussac Bay and hydroelectricity-related damming of three rivers considered part of the SLE beluga critical habitat (Pippard 1985).

A carcass monitoring programme was implemented in 1982 (fully in 1983) to monitor the demography and causes of death, pathologies and other illness in this population through tissue sampling. Every effort was made to ensure that reporting of carcasses and data collection were consistent over the study period. For instance, the existence of the programme was advertised each spring through a publicity campaign requesting the public to report dead beluga. Each reported case was investigated closely to confirm species identity using photographs or visual confirmation by an expert. Field data and samples were collected by three or four experts over the 30-year study period, while the necropsies were conducted by five veterinary pathologists from the same institution (for details see Lesage, Measures et al. 2014; Lair et al. 2015).

In 1988, another programme was undertaken to monitor trends in distribution and abundance using a systematic and repeatable study design (for details see Gosselin et al. 2014). Specifically, photographic aerial surveys were flown every 3-5 years along equally spaced transect lines perpendicular to the main axis of the SLE using two planes, allowing a high-intensity (ca. 50\%) coverage of the entire SLE beluga summer range in a single day.

These two ongoing programmes confirmed that the population numbered only a few hundred individuals (Kingsley \& Hammill 1991) and that it was amongst the most contaminated marine populations on the planet (Martineau et al. 1987; Muir et al. 1990; Wagemann et al. 1990; Martineau et al. 1994), with an incidence of tumours much higher than observed in any other wild population (Béland et al. 1993; De Guise et al. 1994).

From the 1980s through the 2000s, health effects from high contaminant loads were seen as the most imminent threat to the SLE beluga population (Bailey \& Zinger 1995). As a result, research efforts were focused on monitoring population size and documenting pathologies, levels of toxic substances and their potential effects on the beluga immune and endocrine systems (reviewed by Kingsley 2002; Brousseau et al. 2003; Lebeuf 2009). Toxicological studies revealed that SLE beluga had a variety of persistent organohalogen pollutants in their tissues, which were mainly from agricultural and industrial origins. Among these pollutants were PCBs, DDT and their metabolites, heavy metals and PAHs (e.g., Martineau et al. 1987; Wagemann et al. 1990; Muir et al. 1996; Lebeuf 2009). Some of these toxic substances were suspected of inducing immunosuppression and of being responsible for the severity, high prevalence and diversity of lesions observed in the population (De Guise et al. 1994; Martineau et al. 1994; De Guise et al. 1995; De Guise 1998). PAHs, in particular, originating from aluminium smelters, were thought to be responsible for the high rates of cancer documented in the population (Martineau et al. 2002). High burdens of some of these persistent organic pollutants were also suspected of having negative effects on the population's reproductive rate (Martineau et al. 1987). However, scientific evidence supporting correlations between pollutants and pathologies or high rates of cancer in SLE beluga and whether the sample of recovered carcasses was representative of the living population were debated at the time (Addison 1989; Theriault et al. 2002; Hammill et al. 2003).

The long-term programmes monitoring SLE beluga carcasses and abundance revealed a stable number of recovered carcasses over time at around 15 individuals per year (median), including up to three calves annually (reviewed by Lesage, Measures et al. 2014) and a population growing at an abnormally slow pace, if growing at all (Hammill et al. 2007). A demographic analysis conducted in 2007 concluded that the adult mortality rate was comparable to Arctic beluga populations, the emigration rate was likely minimal and the recruitment rate was low and likely responsible for the apparent lack of recovery of the population (Hammill et al. 2007).

Reasons for the non-recovery and low recruitment rate of the population could be a result of one or multiple anthropogenic stressors acting on SLE beluga or their habitat, either independently or in synergy (Beauchesne et al. 2020). SLE beluga live downstream of highly industrialized and urbanized regions discharging toxic chemical substances which eventually reach their habitat (Martel et al. 1986; Gearing et al. 1994; Gobeil et al. 1995; Viglino et al. 2004; Lebeuf \& Nunes 2005). The St. Lawrence River represents the main seaway to interior North America (Fig. 1). Several thousands of ships transit through the SLE beluga habitat each year, chronically elevating ambient noise levels (Simard et al. 2010; Simard et al. 2014; Gervaise et al. 2015). Adding to this noise and potential disturbance are the multiple ferries and the multi-million dollar whale-watching industry operating year-round or seasonally in the SLE beluga critical habitat (Gervaise et al. 2012; Ménard et al. 2014). The collapse of commercially exploited fish stocks in the 1990s (Worm \& Myers 2003; Savenkoff et al. 2007; Cairns et al. 2014) and the population increase of potential competitors, such as grey (Halichoerus grypus) and harp (Pagophilus groenlandicus) seals (Hammill et al. 2015; Hammill et al. 2017), have modified ecosystem trophodynamics (Savenkoff et al. 2007) with potential consequences on prey availability to SLE beluga. 


\section{The canaries in the mine}

In 2012, an alarmingly high number of newborn calves $(n=16)$ were reported dead in the SLE through the carcass recovery programme. This calf stranding rate was five times higher than the annual maxima of three recorded since the beginning of the programme in 1983 and 16 times higher than the annual median calf stranding rate of one during the period 1983-2019 (Lesage, Measures et al. 2014). Four years earlier (in 2008), eight calves and 14 adults had been found dead, an event attributed at the time to a particularly intense and well-documented harmful algal bloom of the toxic dinoflagellate Alexandrium tamarense in the SLE, which had also killed hundreds of seabirds, seals and fish (Starr et al. 2017). A re-examination of beluga deaths between 1983 and 2012 revealed that an unusually high number of calves (10) had also washed ashore in 2010 . This series of high calf mortality events over a short period (2008-2012) led to a coordinated review in 2013, examining long-term information available on multiple aspects of the biology, ecology and the environment of SLE beluga. In years subsequent to the review, additional research efforts were undertaken (e.g., diet, noise exposure and impacts, and health effects of contaminants), along with a close monitoring of anomalies across multiple demographic parameters. The following sections summarize the findings from the 2013 review (see also DFO 2014) and the various studies subsequent to it. This review article also updates the analysis of sex- and age-specific carcass recovery rates presented as part of the 2013 review (Lesage, Measures et al. 2014) by incorporating seven additional years of data: 2013-19.

\section{Population trends and dynamics}

Abundance estimates obtained from visual line-transect surveys (2001-09) and photographic strip-transect surveys (1988-2009) indicated that the 2009 estimatethe latest available for this population at the time of the 2013 review-was the lowest in both survey time series (Gosselin et al. 2014). A photogrammetric analysis to detect calves and yearlings (zero and one year in age) in aerial images from the photographic surveys (Desrosiers 1994 ) indicated a decrease in these age class proportions within the population from $15-18 \%$ in the 1990 s to $3-8 \%$ in the 2000s (Gosselin et al. 2014). The incorporation of this information in an age-structured population model, along with abundance estimates from the photographic survey time series (1988-2009; summarized by Gosselin et al. 2014) and numbers of dead calves and non-calves reported through the carcass monitoring programme (Lesage, Measures et al. 2014), indicated that several aspects of SLE beluga demography had changed over time (Mosnier et al. 2015). Modelling showed that over the period 1983-2012, the population had shifted from a relatively stable to an unstable state starting around 1999 (Fig. 2). From 1983 to 1998, the calf mortality rate was relatively stable (median values: $14-27 \%$ ), as was the pregnancy rate (about 30\%, with small peaks every three years) and the population age structure (50.5\% adults, $42 \%$ juveniles and $7.5 \%$ calves). Starting in 1999 and at least until 2012 (last year modelled), an increase in inter-annual variability was noted in calf mortality and pregnancy rates, along with a decline in the proportion of juvenile individuals (1-7 years of age) to 33\% in 2012 (Mosnier et al. 2015). There was no clear pattern in adult mortality over the modelled period, 1983-2012 (Fig. 2). However, the model predicted a change in female reproduction during the last few years of the modelling exercise, when calf mortality was above the long-term median. The reproductive cycle shifted from a threeyear cycle, with a third of mature females pregnant each year, to a two-year cycle, with about half of the females pregnant (Mosnier et al. 2015). These predicted changes in mortality and reproductive schedules resulted in the population shifting from a stable or slightly increasing trend at about $0.13 \%$ per year until 2002 to a declining trend at an average annual rate of $-1.13 \%$ per year and an estimated population size of 889 individuals (95\% CI: 672-1167) in 2012 (Mosnier et al. 2015). An additional photographic aerial survey was conducted in 2019 to update population abundance estimates, trends and demographic parameters; results are pending.

These model-derived demographic parameters were consistent with independent empirical observations made in the context of a long-term photo-identification programme of live SLE beluga from 1989 to 2012 (Michaud 2014). Specifically, an index for the proportion of immature individuals in the population (grey animals), which included juveniles and young adults, increased slightly from 1989 to the mid- and late 2000s. Consistent with model predictions, this period was followed by a decline in the representation of immature individuals in the population until the last year modelled in 2012 (Michaud 2014). Field data collections also indicated that years predicted to be associated with high pregnancy rates in the model for the period 2004-2012 were followed by years of high calf production in the field, building our confidence in model predictions.

\section{Carcass monitoring and cause of death}

The number of beluga recovered each year through the carcass monitoring programme was variable between 

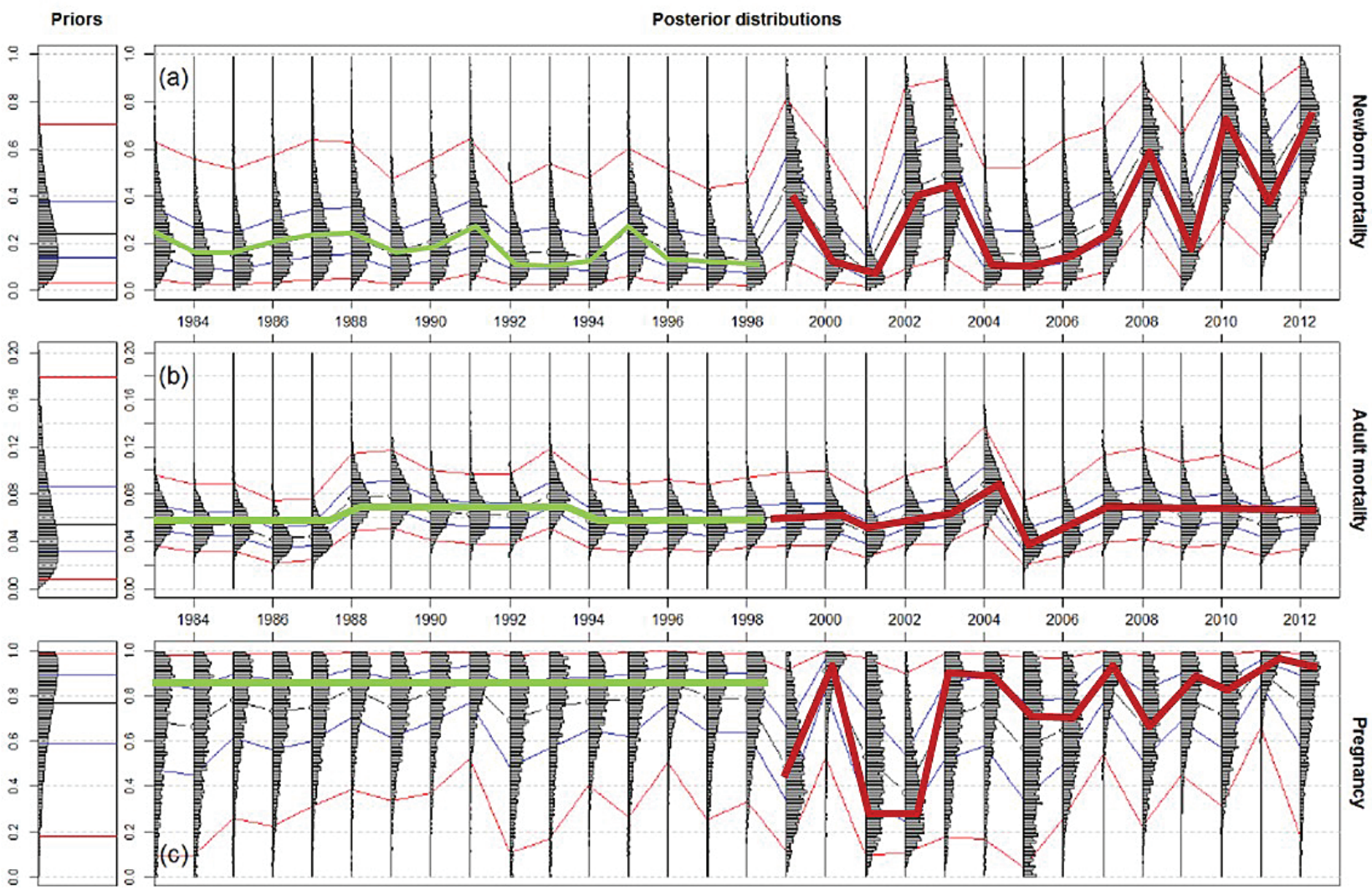

Fig. 2 Predicted patterns of (a) calf mortality, (b) adult mortality and (c) pregnancy rate for SLE beluga over the period 1983-2012, based on a model incorporating abundance estimates, per cent representation of calves and yearlings from photographs taken on systematic aerial surveys, and carcass recovery for calves (zero year old) and non-calves (one year in age and older). The bold lines emphasize the periods of stability (green: 1983-1998) and instability (red: 1999-2012) in demographic parameters. Adapted from Mosnier et al. (2015).

years for the different age and sex classes but appeared relatively stable from 1983 to at least 2007 (Fig. 3). Trends emerged for some age and sex classes when carcasses from the most recent period (2013-19) were added to the time series examined during the review (19832012). Specifically, the number of dead calves, which had increased in 2008-2012, continued to remain higher than the long-term maxima observed from 1983 to 2007 (three individuals) in 10 of the 12 most recent years, that is, 2008-2019 (Fig. 3). In contrast, adult animals (aged eight years or more) tended to be found less often after 2010. A sex-specific analysis revealed that this decrease in adult mortality was entirely attributed to the decline in adult male representation among carcasses (Fig. 4a). The exact timing of this decline, however, remains uncertain. The most parsimonious model suggests that it began in the late 1990s (Fig. 5; generalized additive model with penalized cubic splines smooth, best model based on lowest AIC: 3 knots, $e d f=2.0, d f=4$, deviance explained $=$ $33.4 \%)$. However, the downward trend is heavily driven by the 2010-19 data; allowing more knots to the generalized additive model or using a different statistical approach (e.g., broken stick or sequential analysis) would have resulted in a decline at a later date (not shown). The decrease in male representation among adult carcasses was strongly correlated (Pearson's $r=-0.86$ ) with an increase in the sex ratio among deaths towards adult females (Fig. 4b; best model: linear regression, $d f=3$, $p<0.001)$ even if the absolute number of adult females among carcasses, although variable among years, did not change over the study period (best model: linear regression, $d f=3, p=0.70$; Fig. 4a). Similar to adult females, the number of carcasses of juvenile individuals (i.e., $1-7$ years old) remained stable over the study period (Fig. 3b; best model: linear regression, $d f=3, p=0.09$, AIC for linear and non-linear regressions were identical).

Hypotheses to explain this sex-related difference in carcass recovery rate are multiple. While a brief overview is provided here, a thorough investigation of each hypothesis will be required before any conclusion can be 

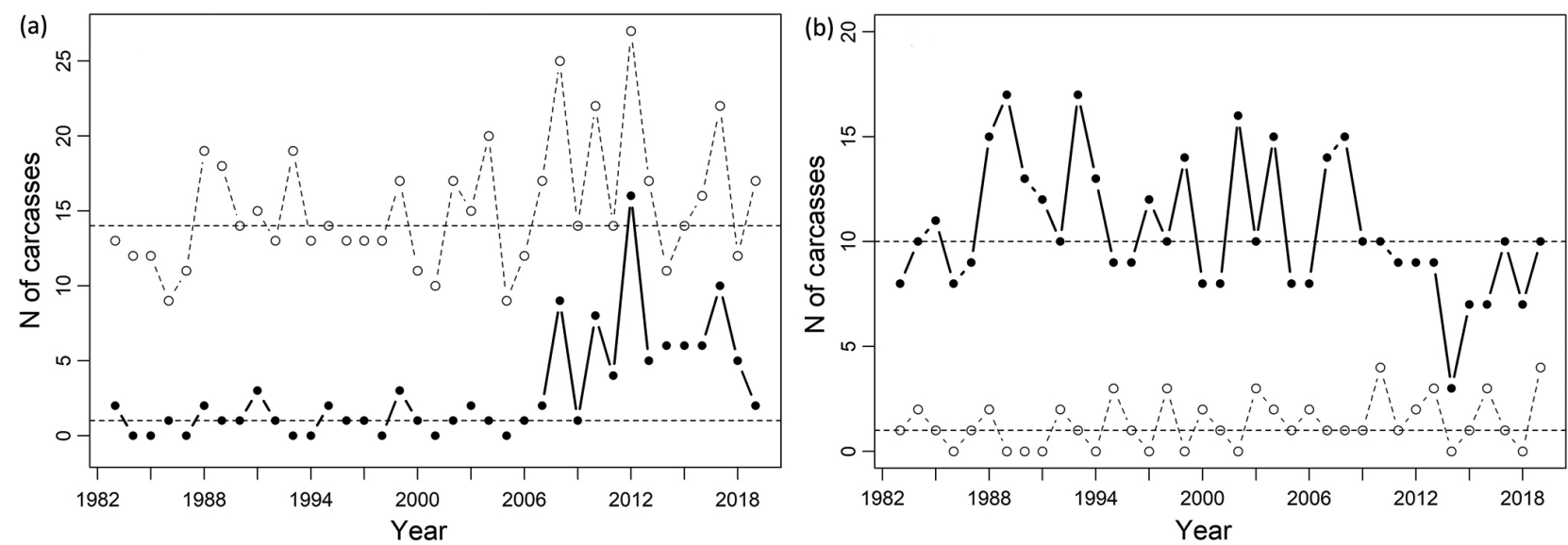

Fig. 3 Reported cases of dead beluga in the estuary and Gulf of St. Lawrence over the period 1983-2019. (a) Total cases (open circles) and calf carcasses (solid circles) and (b) adult carcasses (eight years or older, solid circles) and juvenile carcasses (1-7 GLGs, open circles). The dotted horizontal lines represent the median for each time series. Adapted from Lesage, Measures et al. (2014).
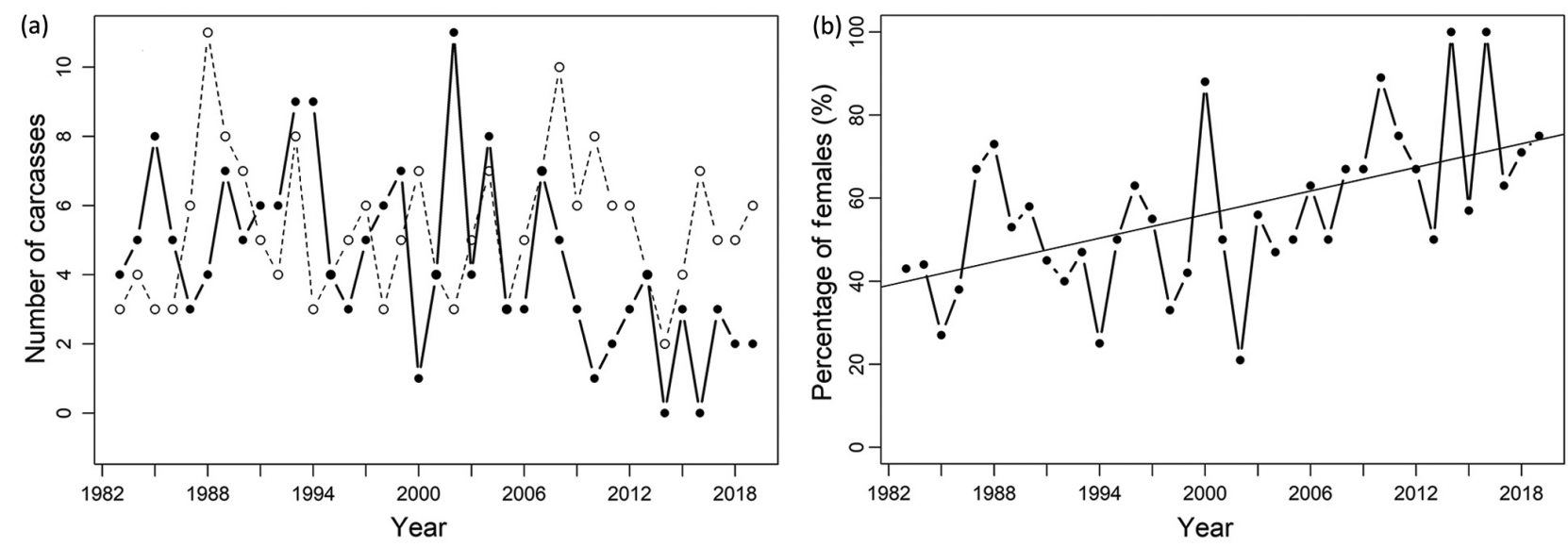

Fig. 4 Number of beluga carcasses recovered in the estuary and Gulf of St. Lawrence over the period 1983-2019, expressed in terms of (a) number of adult males (back circles) and females (open circles) and (b) percentage of adult females. Lines indicate significant regressive relationships over time. Adapted from Lesage, Measures et al. (2014).

drawn from the observed patterns. At least during part of the year, adult males and females are spatially segregated, leading to differential exposure to environmental stressors and differential access to prey items (Michaud 1993; Mosnier et al. 2016; Lesage et al. 2020). The lower representation of adult males in the recovered carcasses could arise from a progressive decrease in detection probability, for instance, as a result of a change in adult male distribution (e.g., due to ecosystem change) towards areas that are less urbanized or less accessible to humans. Males could also have decreased in abundance over time compared to females, resulting in fewer relative deaths. Male survival may also have increased compared to adult females, for instance, through a progressively lesser exposure to habitat degradation or threat factors, or through access to more profitable prey compared to females. Alternatively, the health and survival of both males and females might have improved because of a reduction of potential stressors (e.g., contamination) or higher prey availability but additional sources of mortality prone to affect females might have eliminated these benefits for them. While one of these hypotheses is elaborated below, all of them are plausible. The timing of the change in adult male representation in the recovered carcasses will be a key in assessing the likelihood of each of these hypotheses.

Complete necropsies of 222 SLE beluga conducted between 1983 and 2012 revealed that the main cause of death for this population was an infectious disease, 


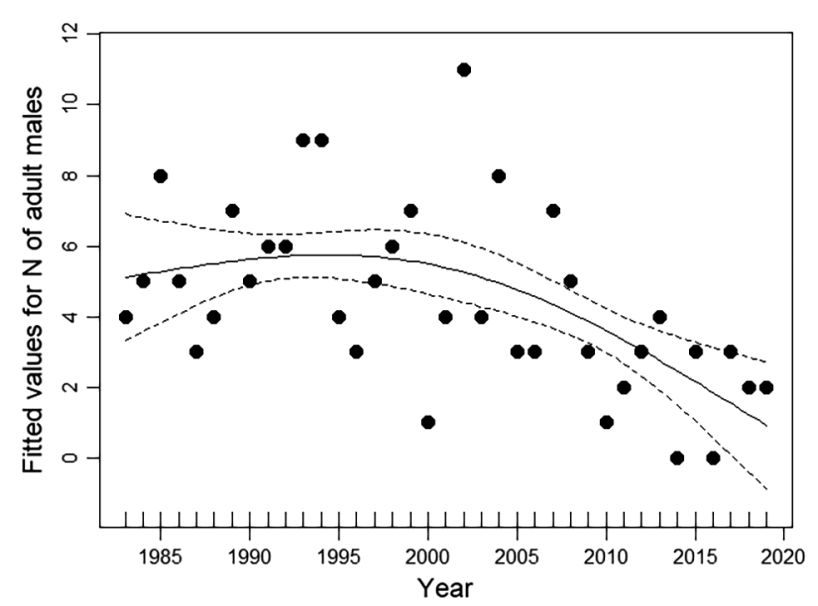

Fig. 5 Predicted (curve with 95\% Cl) and observed (black circles) change in adult male representation among the beluga carcasses recovered in the estuary and Gulf of St. Lawrence over the period 1983-2019. Model selection was based on the lowest AIC and degrees of freedom when AIC values were within 2 units. Non-linear regressions used a penalized cubic regression splines approach for estimating the smoothing parameter. Optimal degree of smoothing (number of knots) was determined while taking into account residual deviance and effective degrees of freedom (edf; R package mgcv). Note that the timing of the decline is uncertain. The analysis is heavily driven by the 2010-19 data, but is constrained by the number of knots in the analysis.

which accounted for half of the cases in juveniles and one-third (32\%) of all cases (Lair et al. 2016). Malignant neoplasia (tumours) was the cause of death for $14 \%$ of the beluga and affected only beluga of 28 years or older, whereas dystocia or post-partum complications caused the death of $19 \%$ of sexually mature females. A small fraction of deaths were attributed to vessel strikes $(4 \%)$, primary starvation $(2 \%)$, fishing-gear entanglement and $(1 \%)$ and intoxication (one case). The absence of neoplasia was also noted for SLE beluga born after 1971 (Lair et al. 2016).

Lair et al. (2016) postulated the existence of a relationship between the reduction of gastrointestinal cancer and the cessation in 1976 of PAH emissions from changes in the aluminium production process and stricter environmental regulations. A recent study examining PAH-DNA adducts in beluga intestine lent support to this hypothesis (Poirier et al. 2019). Banning PCBs in 1979, which reduced the levels of PCBs in beluga over time (Lebeuf, Measures et al. 2014), may also have contributed to the progressive disappearance of some neoplastic diseases in this population (Martineau et al. 2002; Lair et al. 2016). A reduction in non-sex-specific cancers should have improved the health of, and increased survival among, both males and females (i.e., reducing numbers in reported carcasses). Whether the improvement in survival occurred equally and simultaneously for males and females, and whether it was progressive or instead occurred when contaminant levels fell below a certain level in beluga tissues, is unknown. Parturition-associated mortality, a cause specific to females and which occurred only occasionally from 1983 to the early 2000s, increased in frequency in the 2000s (Lair et al. 2016). Assuming a persistence of this phenomenon in the 2010s, it could have masked an increase in the survival rate of adult females from an overlapping reduction in cancer-related mortalities and led to the stable pattern in female mortality observed over time (Fig. 4a).

\section{Potential stressors and their effects}

There are also competing, although not exclusive, hypotheses for the observed high calf mortality and change in the demography of the SLE beluga population. These include health problems or impaired reproductive functions from the toxic effects of specific chemical compounds on endocrine and immune functions; perturbation of critical activities (e.g., parturition and foraging) from chronic vessel exposure or isolated or repeated disturbance; fishery- or climate-related changes in ecosystem structure leading to a decrease in habitat quality and prey availability or quality; and recurring stochastic events such as harmful algal blooms (DFO 2014).

SLE beluga have a long history of exposure to a variety of POPs, such as DDT, PCBs, Mirex, toxaphene, PAH, dioxins and furans (reviewed by Lebeuf 2009; see also Lebeuf, Raach et al. 2014; Simond et al. 2017). Decreasing in the environment since at least 1987, these pollutants are unlikely to be the primary factor for the recent increase in mortality and population decline (Muir et al. 1996; Lebeuf, Raach et al. 2014); however, new contaminants from the 1980s, such as toxic flame retardants (PBDEs), have accumulated at an exponential rate in beluga and their environment in the 1990s, with PBDEs remaining at maximum levels in beluga since that time (De Wit 2002; Lebeuf, Measures et al. 2014; Lebeuf, Raach et al. 2014; Simond et al. 2017).

PBDEs and several other POPs can have endocrine-disrupting effects in a variety of species including humans and other mammals, with possible impacts on reproduction, immune system, behaviour and offspring development (reviewed by Lebeuf 2009; Lebeuf, Raach et al. 2014; see also Costa et al. 2014; Yu et al. 2015). An analysis comparing PBDE concentrations in adult females and calves among three periods (1995-2001, 2002-07 and 2008-2011) was unsuccessful at identifying the role of PBDEs in the recently elevated frequency of complications 
at parturition and mortality of calves (Lebeuf, Measures et al. 2014). This is not to say that PBDEs have no detrimental effects on health but that the study, with its specific design, does not reveal a direct relationship between PBDE burden and beluga health linked to mortality. A negative effect of PBDE homologs on blood thyroid hormone levels has been documented in beluga in Svalbard, Norway (Villanger et al. 2011). The negative effects of hypothyroidism on parturition and foetal health and survival, and of foetal exposure to PBDE on calf survival and cognitive abilities, have been reported in humans and other animals (reviewed by Lair et al. 2016). While there is yet no evidence for PBDE-related hypothyroidism in SLE beluga, a correlation between thyroid-related gene expression and levels of some emerging halogenated flame retardants has been documented in this population (Simond et al. 2019). However, a mismatch between the period of increased calf mortality and parturition complications (the late 2000s) and of high concentrations of PBDEs in SLE belugawhich have plateaued since 1998-indicates a need for further investigation (Lair et al. 2016).

Chronic exposure to noise and its potential effects on marine mammals is a concern worldwide (Clark et al. 2009; Boyd et al. 2011; Williams et al. 2015). In the SLE, chronic commercial shipping and ferry operations, as well as seasonal whale-watching and recreational activities, raise ambient noise in the beluga habitat (Simard et al. 2010; McQuinn et al. 2011; Gervaise et al. 2012). Between 5000 and 6000 transits from merchant ships are reported each year through the critical habitat of SLE beluga (Fig. 1; McQuinn et al. 2011). There are 11 marinas near SLE beluga critical habitat, four ferry services operating within its bounds, resulting in tens of thousands of ferry transits each year, and a multi-million dollar whale-watching industry, mainly targeting species other than beluga but operating within its critical habitat (Ménard et al. 2014). Vessel traffic from tourism and whale-watching activities peak in July-August, when SLE beluga give birth (Sergeant 1986). While SLE beluga appear more tolerant to noise than beluga populations in the Arctic, where there is comparatively little shipping (Finley et al. 1990), SLE beluga are not immune to deleterious effects from noise exposure. Noise can have negative effects on animals in a number of ways, including masking vocalizations and important signals, reducing acoustic space, diverting attention, disrupting natural behaviour, habituation (i.e., learned deafness) and causing chronic stress (Erbe et al. 2018). Noise can also limit the energy and time allocated to critical activities like foraging or impair social interactions by, for example, interfering with the acoustic bond between mother and calf (Tyack \& Clark 2000). Vocal responses to noise have been documented in SLE beluga (Lesage et al. 1999; Scheifele et al. 2005), and their abandonment of Tadoussac Bay established after a marina is suspected to be a consequence brought by disturbance from increased vessel traffic and noise exposure (Pippard 1985). Ferries and other large ships can reduce beluga acoustic space considerably. At the mouth of the Saguenay River where as many as three ferries operate simultaneously, acoustic space has been reported at a fraction (30\%) of its expected value under natural conditions during half of the time, regardless of the beluga call frequency (Gervaise et al. 2012). Beluga emit contact calls, which can be heard over ranges that are 18 times larger for adults and subadults than for newborn calves (Vergara et al. 2021 [this special cluster]). In a key habitat of the SLE (Baie Sainte-Marguerite in the Saguenay River), vessel noise reduced the communication range from a median of $6.7-2.9 \mathrm{~km}$ for adults and subadults and from a median of 360-170 $\mathrm{m}$ for newborn calves. These $57 \%$ and $53 \%$ reductions in communication range for calls with a known function are evidence that anthropogenic noise from marine traffic may impair communication, and especially mother-calf contact.

The exposure of SLE beluga to noise varies between habitats and is highest near the shipping lane and at the Saguenay River mouth, where a marina and most of the whale-watching companies are based (Fig. 1; McQuinn et al. 2011). Noise exposure is lowest in habitats located along the south shore, where traffic of all sources is currently light (McQuinn et al. 201 1; Lesage, McQuinn et al. 2014; Roy \& Simard 2015). On a daily basis, merchant ships in the SLE repeatedly expose a substantial proportion of the beluga population (15-53\%, depending on traffic direction) to noise levels likely to interfere with their behaviour, and the vast majority of exposed animals $(72-81 \%)$ are females with calves or juveniles (Lesage, McQuinn et al. 2014).

Shipping traffic in the SLE has likely been lighter in the 1990s and 2000s compared to the 1970s or 1980s (Dionne 2001). While interannual variations are noted, there is no evidence for any substantial increase in traffic volume at least until 2012 (McQuinn et al. 2011; Ménard et al. 2014). Whale-watching operations in traditional sectors of activity (i.e., in the SLE downstream of the Saguenay River where large whales are located; Fig. 1) have also remained relatively constant over time, even decreasing slightly in the 2010s (Ménard et al. 2014). However, newly established companies specifically targeting beluga have increased whale-watching operations from 2004 to 2012 in non-traditional sectors located in the upstream portion of the SLE and within the beluga critical habitat (Ménard et al. 2014). Recreational activities have also increased in this sector since 2004 (Ménard et al. 2014). Indicators for the volume of recreational activities in the beluga summer 
range indicated a coincidence of the high calf mortality events from 2010 and 2012 with a high number of boat-nights in marinas, high per cent days with law-infraction reports for interactions with beluga and clement weather conditions, that is, low precipitation and high air temperature (Ménard et al. 2014). Physical or acoustic interferences from motorized or non-motorized vessels (e.g., kayaks) with parturition, lactation or mother-calf acoustic bond can induce parturition-related complications or abandonment of the calf. The continuous presence of a human observer during parturition has been reported to induce such complications in cows (Mee 2008). Although it is unknown if disturbance during the calving season was specifically higher during the high mortality events from 2010 and 2012 than in previous years, the persistence of high calf mortality after 2012 in spite of variable weather conditions suggests that this factor might not be the main cause for the increased calf mortality observed over the past decade.

Stochastic events such as harmful algal blooms were also among the factors examined in the context of the recent increase in calf mortality. Red tides caused by blooms of the dinoflagellate Alexandrium tamarense and their associated release of phycotoxins are responsible for outbreaks of paralytic shellfish poisoning and can pose serious health risks for humans and marine organisms (Geraci et al. 1989; Landsberg 2002). Three major red tides were documented over the past two decades in St. Lawrence: in 1996, 1998 and 2008 (Scarratt et al. 2014; Starr et al. 2017). The 2008 red tide was especially well-documented, and a relationship between high cell concentrations of $A$. tamarense near Tadoussac, in the heart of SLE beluga habitat, and the high mortality of beluga was established for that year (Scarratt et al. 2014). There was no evidence for such red tides during the high mortality events from 2010 and 2012 (Scarratt et al. 2014).

\section{Diet and ecosystem change}

Changes in the St. Lawrence community structure have occurred over time as a result of climate variability and anthropogenic factors such as the collapse of demersal fish stocks from overexploitation and ocean warming (Worm \& Myers 2003; Savenkoff et al. 2007). These environmental changes likely have modified prey availability, with potential effects on predator population dynamics (e.g., Plourde, Grégoire et al. 2014). A time-series analysis of 28 ecosystem indices of habitat quality, prey availability and physical environmental variability of the Gulf of St. Lawrence over the period 1990-2012 highlighted a major shift in the ecosystem in the late 1990s, that is, approximately at the time when beluga population dynamics started to change (Plourde, Galbraith et al. 2014). The ecosystem shifted from a period of above long-term averages, characterized by a relative abundance of prey and cool environmental conditions, to a period of below longterm averages when Gulf of St. Lawrence stocks of Atlantic spring herring (Clupea harengus), Atlantic cod (Gadus morhua) and other large demersal fish (NAFO Division 4T) had collapsed and were at their lowest biomass, and when the environment was subject to below-average ice conditions and above-average water temperatures. Trend analysis of these variables since 1971 also identified unprecedented extremes in environmental conditions from 2010 to 2012, with particularly high temperatures and low indices for ice duration and volume (Plourde, Galbraith et al. 2014). These extreme conditions have persisted at least to 2019 (Galbraith et al. 2020).

An optimum ice condition for calf survival is likely to exist based on the U-shaped relationship predicted between ice duration and calf mortality for SLE beluga (Williams et al. 2017). In the Arctic, females tend to avoid very high or very low ice cover in the fall (Barber et al. 2001), supporting model predictions indicating that extreme ice cover may be unfavourable to calf survival. While the physical presence of ice could reduce energy output for adults and calves by offering shelter against storm (Barber et al. 2001), its relative benefits to beluga energetics remain uncertain. Ice also influences the potential for prey to concentrate in the marginal ice zone (Fréchet 1990) and the biomass and timing of spawning of some important beluga prey, such as capelin (Mallotus villosus; Buren et al. 2014; Lesage et al. 2020). As a result, extremes in ice conditions might affect calf survival by reducing energy intake of pregnant females during winter (Truchon et al. 2013) and during critical periods such as the spring when intense feeding on prey such as spawning capelin and herring likely occurs before calving (see Lesage et al. 2020). Elevated sea surface temperatures in the summer months have also been predicted to have a negative effect on calf survival (Williams et al. 2017).

Calf mortality was also inversely related to biomass indices for some beluga prey such as spring herring (NAFO Division 4T) and demersal species (NAFO Division 4Tw), which, together with sea-ice indices and sea-surface temperature, accounted for $82 \%$ of the deviance of the model predicting calf mortality (Williams et al. 2017). Conversely, prey availability and variations in environmental conditions were not good predictors of adult female mortality and fecundity. Such an effect on reproductive success or survival would be likely to arise from extreme changes in adult female body condition.

The coincidence of the shift in the St. Lawrence community structure and environmental conditions with the 
change in beluga population dynamics, including higher calf mortalities in periods of extreme conditions (starting around 2010), supports the hypothesis highlighting the role of ecosystem change in beluga population dynamics, potentially through effects on reproductive success and adult female body condition. While data on diet remain fragmentary for this population, studies from the 1930s and from more recent years (1987-2019) suggest that pelagic species such as capelin and herring, sand lance (Ammodytes spp.) and large demersal species such as cod (Gadus morhua and G. ogac) and redfish (Sebastes sp.) may be seasonally important in the SLE beluga diet (Vladykov 1946; Lesage 2014; Ferchoui 2019; Lesage et al. 2020). Evidence for a potential shift in SLE beluga diet has been reported through an assessment of SLE beluga dietary sources and trophic position from 1988 to 2012, which identified a progressive decrease (approximately one part per mil, equivalent to one trophic level), in a tracer of carbon sources starting around 2003 (Lesage 2014). A decline in a tracer of trophic position (nitrogen isotope ratios), although overall modest at approximately $0.6 \%$ over 10 years, was also observed over the same period (Lesage 2014). Whether these changes reflect a change in beluga diet or a change in the isotopic signature of their prey is unknown.

Some prey species and feeding periods may be critical for pregnant or lactating females to ensure successful reproduction and weaning of calves (Lockyer 1986; Jönsson 1997; Miller et al. 2011). This appears to be the case for the SLE beluga population during spring feeding, when beluga rapidly accumulate lipid in their blubber (Casgrain 1873; Vladykov 1944; see Lesage et al. 2020). Food intake increases 1.5- to twofold in late pregnancy and peaks at fourfold their normal intake during the first month after giving birth in captive beluga (Kastelein et al. 1994). There is currently little information available on SLE beluga body condition. However, a recent study using the sum of blubber fatty acids as an indicator of beluga body condition suggests that it has deteriorated from 1998 to 2016 in both males and females (Bernier-Graveline et al. 2021). Whether a deteriorating body condition in pregnant females played a role in the increased calf mortality and parturition-associated complications observed in recent years is currently unknown (Lair et al. 2016). In other mammals, such as cows, nutritional stress during the last semester of pregnancy has been associated with an increased risk of parturition-associated complications (e.g., dystocia) (Gruner 1973). Disturbance of parturient females and exposure to endocrine-disrupting chemicals such as PBDEs also represent risk factors linked to parturition-associated complications (Lair et al. 2016).

\section{Relative importance of the multiple stressors}

A recent population viability analysis incorporating environmental stressors provided insight into how the SLE beluga population was likely to respond to changes in environmental conditions and varying levels of three anthropogenic threats (Williams et al. 2017). The analysis incorporated PCB contamination as a proxy for other contaminants, the combined biomasses of demersal fish and spring herring, and noise-mediated effects on foraging efficiency as potential stressors acting on population dynamics, while accounting for potential effects of changing sea-ice conditions and seawater temperatures. With the caveat that this model was data limited and could only account for the relationship between these stressors or the environment and calf mortality, the study indicated that prey availability contributed the most to changes in calf mortality, followed by noise and PCBs. Among the management scenarios that explored potential reductions in threats separately and in combination, only the scenario in which all three threats were mitigated simultaneously was likely to create the necessary resilience for the population to persist in the context of the current climate change and warming conditions (Williams et al. 2017).

\section{Conclusions and perspective}

The very slow population growth rate observed during the 1980s and 1990s despite the total halt on hunting suggests that population growth was already constrained by anthropogenic stressors or sub-optimal environmental conditions associated with local climate, or both. While a harmful algal bloom event was likely responsible for the unusually high calf mortality in 2008, the timing of the change in population dynamics and of increased calf mortality suggests that warming environmental conditions and a decrease in sea-ice extent and duration, with their cascading effects on ecosystem structure (Smetacek \& Nichol 2005), may be key drivers of the current population decrease and the persistently high calf mortality. The apparent deterioration of SLE beluga body condition over the past 20 years supports a hypothesis in which climate or fishery-driven impacts on energy balance likely play an important role, by reducing prey availability, quality or both. A similar, although weak, trend in body condition (blubber thickness) and body growth rate has been documented in Beaufort Sea beluga from 1997 to 2008, although causative factors remain unclear (Harwood et al. 2014). Poorer body condition can also arise solely from an increase in energy output caused by anthropogenic stressors, for example, repeated avoidance response 
or disruption of foraging by vessel proximity, or noisemediated reduction of foraging efficiency (Lusseau $\delta$ Bejder 2007; Christiansen et al. 2015; Pirotta et al. 2015; Senigaglia et al. 2016). In food-limited conditions or in the case where females are accompanied by a dependent calf, the ability of an individual to cope with these stressors can be reduced (e.g., Williams \& Loren 2009; Senigaglia et al. 2016). Therefore, while a food-mediated effect on body condition and reproductive output represents a highly plausible explanation for the poorer body condition and current demographic situation of the SLE beluga population, other stressors should not be dismissed as potential contributors to the challenges that this beluga population face in its changing environment.

The vulnerability of a population to changes in its environment is a function of its exposure, sensitivity, and adaptive capacity (Dawson et al. 2011). Exposure depends on the magnitude and rate of change; the sensitivity depends on life-history traits such as habitat specificity, dietary specialization, range size, population size and reproductive rate; and adaptive capacity depends on habitat loss and fragmentation, and also on intrinsic traits such as phenotypic plasticity, and dispersal and colonization capacity (Ofori et al. 2017).

The beluga is fundamentally a polar species that has adapted over evolutionary time to an environment with a permanent sea-ice cap as its most defining character (O'Corry-Crowe 2008; Kovacs et al. 2011). Beluga in the SLE are at the southern margin of the species distribution, in an environment where only annually forming ice is present, and its formation is only seasonal. Beluga have persisted in this environment over the past 10000 years (Harington 2008) and are presumably welladapted to an extreme and dynamic environment given their anatomy and primary Arctic distribution. Climate models are forecasting that the SLE will be a nearly icefree environment within 50-80 years (Ruest et al. 2016). The rate of the current climate warming and the high degree of isolation of the SLE beluga population may hinder their capacity to adapt to these changes and to survive in an ice-free or nearly ice-free and warm environment (O'Corry-Crowe 2008).

Beluga as generalist feeders are better adapted than specialists for coping with changes in prey assemblages (Kassen 2002; Dennis et al. 2011). In the Canadian Arctic, where temperate species such as sand lance and capelin are expanding their range as a result of warming conditions (Wassmann et al. 2011), beluga responded to this change in prey availability by incorporating these new prey items into their diet (Kelley et al. 2010; Marcoux et al. 2012), although with unknown consequences related to prey quantity and/or quality on their health. Whether a similar pattern will or has occurred in SLE beluga as a result of the expansion or higher abundance of more temperate fish or invertebrate species is unknown (Lesage et al. 2020). The apparent deterioration of their body condition over the past 20 years (Bernier-Graveline et al. 2021) suggests that adaptation to the changing ecosystem has been challenging. The reduction in ice cover may increase interspecific competition as other species extend the duration of their stay or expand their range (Kingsley 2002). The continuing decrease in oxygen levels (i.e., hypoxia) in waters of the SLE and Gulf of St. Lawrence, partly resulting from the decreased proportion of the oxygen-rich Labrador Current water entering this region (Gilbert et al. 2005), is likely to affect biodiversity and productivity (Diaz \& Rosenberg 2008), with potential effects on the availability of some of beluga prey (Lavaud et al. 2019).

With 1938 as a baseline, SLE beluga occupy an area that represents $65 \%$ of their historical range (COSEWIC 2014). Whether this range contraction is the consequence of population decline, as appears to be the case for Cook Inlet beluga (Rugh et al. 2010), or whether it occurred as a result of changes to their habitat or over-hunting at some historical sites is unknown. The species is known for its natal philopatry to summer concentration areas and to migratory circuits within regions, with migration routes and site fidelity being culturally learned (Caron \& Smith 1990; de March \& Postma 2003; Turgeon et al. 2012; Colbeck et al. 2013; O'Corry-Crowe et al. 2018). This cultural inheritance likely also explains the resilience of beluga movements to inter-annual variation in sea-ice conditions, although anomalies in migration patterns can occur in highly anomalous ice years ( $\mathrm{O}^{\prime}$ Corry-Crowe et al. 2016). Fidelity to breeding or feeding sites, such as those documented in beluga and other species like southern right whale (Eubalaena australis) and humpback whales (Megaptera novaengliae), may make these species more prone to extinction risk compared to other cetaceans or to pinnipeds (Valenzuela et al. 2009; Baker et al. 2013; O'Corry-Crowe et al. 2018). Stable matrilineal groups have long been seen as the cornerstone of beluga society when interpreting the aspects of their ecology and behaviour, but a recent study indicates that beluga groupings can also be organized around close paternal relatives (O'Corry-Crowe et al. 2020). The complex social system and the high degree of sociality of beluga and other odontocetes may further increase their vulnerability to extinction risk (Wade et al. 2012). Predictions related to these life-history traits, which appear to reduce the potential for dispersal to new areas more suitable for their survival, could explain in part the absence of recolonization of abandoned or over-hunted sites (Mosnier et al. 2010; Colbeck et al. 2013). 
Together, these characteristics make the beluga a species that is considered moderately vulnerable to climate change or environmental variability (Laidre et al. 2008). However, vulnerability is likely to be higher for the SLE beluga population given its location at the southern margin of the species range and the low probability of migrants from other populations replenishing its declining population (O'Corry-Crowe et al. 2016). The frequency, intensity and geographic extent of harmful algal blooms appear to be increasing worldwide as a result of climate change, coastal eutrophication and other environmental perturbations and are expected to increase the frequency of associated mortality events (Van Dohal 2000; Gulland $\&$ Hall 2007). These multiple predictions underscore the need for immediate actions to be taken to reduce the population's exposure to non-climatic stressors.

Since the first recovery plan was proposed in 1995 for SLE beluga (Bailey \& Zinger 1995), multiple actions have been implemented to improve the quality of its acoustic and physical environment (reviewed in DFO 2017). The regulation of toxic chemical substances such as PCBs and PAHs, although not in response to beluga decline-they were regulated in the 1970s-may have reduced the incidence of cancer in adult beluga (Lair et al. 2016), showing that appropriate specific actions can result in measurable positive impacts on the population. While recovery measures implemented to date have allowed the population to stabilize prior to 2000 , they were insufficient to allow the population to grow at the targeted $2 \%$ growth rate and to cease decreasing (DFO 2017). Additional actions are necessary and have been proposed to address the various threats (DFO 2017, 2020). In the case of noise, a number of actions have been thoroughly examined for their potential benefits and capacity to decrease exposure across beluga habitats (e.g., Lesage, McQuinn et al. 2014; Chion et al. 2017). The variety of threats, the number of stakeholders that need to be involved in the implementation of recovery actions and inherent delays associated with regulatory processes will remain a challenge, but the timely implementation of additional and necessary recovery measures is possible.

\section{Acknowledgements}

I thank Dr Tracy Romano and the organizing committee for their invitation to prepare this paper and presentation at the Second International Workshop on Beluga Whale Research and Conservation in 2019, and the many individuals and organizations whose research contributed to the 2013 review. I am also grateful to Serge Aucoin and Jory Cabrol for kindly reviewing and commenting on an earlier version of this manuscript, to Drs
Arnaud Mosnier and Stéphane Plourde for stimulating discussions, to Jean-François Ouellet and Samuel Turgeon (Parcs Canada) for the map and traffic data, and to Drs Brian Blamer and Marie-Francoise Van Bressem for comments on the submission.

\section{Disclosure statement}

The author reports no conflict of interest.

\section{Funding}

This work has been supported by the Species at Risk programme of Fisheries and Oceans Canada.

\section{References}

Addison R.F. 1989. Organochlorines and marine mammal reproduction. Canadian Journal of Fisheries and Aquatic Sciences 46, 360-368, doi: 10.1139/f89-047.

Bailey R. \& Zinger N. 1995. St. Lawrence beluga recovery plan. Toronto: World Wildlife Fund.

Baker C.S., Steel D., Calambokidis J., Falcone E., GonćalezPeral U., Barlow J., Burdin A.M, Clapham P.J., Ford J.K.B., Gabriele C.M., Mattila D., Rojas-Bracho L., Straley J.M., Taylor B.L., Urbàn J., Wade P.R., Weller D., Witteveen B.H. \& Yamaguchi M. 2013. Strong maternal fidelity and natal philopatry shape genetic structure in North Pacific humpback whales. Marine Ecology Progress Series 494, 291-306, doi: 10.3354/meps 10508 .

Barber D.G., Saczuk E. \& Richard P.R. 2001. Examination of beluga-habitat relationships through the use of telemetry and a Geographic Information System. Arctic 54, 305-316.

Beauchesne D., Daigle R.M., Vissault S., Gravel D., Bastien A., Bélanger S., Bernatchez P., Blais M., Bourdages H., Chion C., Galbraith P.S., Halpern B.S., Lavoie C., McKindsey C.W., Mucci A., Pineault S., Starr M., Ste-Marie A.-S. \& Archambault P. 2020. Characterizing exposure to and sharing knowledge of drivers of environmental change in the St. Lawrence system in Canada. Frontiers in Marine Science 7, article no. 383, doi: 10.3389/fmars.2020.00383.

Béland P., De Guise S., Girard C., Lagacé A., Martineau D., Michaud R., Muir D.C.G., Norstrom R.J., Pelletier É., Ray S. \& Shugart L.R. 1993. Toxic compounds and health and reproductive effects in St Lawrence beluga whale. Journal of Great Lakes Research 19, 766-775.

Bernier-Graveline A., Lesage V., Cabrol J., Lair S., Michaud R., Rosabal M. \& Verreault J. 2021. Lipid metabolites as predictors of energy reserves in highly contaminant-exposed belugas from the endangered St. Lawrence Estuary population. Environmental Research 192, article no. 110272 , doi: 10.1016/j.envres.2020.110272.

Boyd I.L., Frisk G., Urbàn E., Tyack P., Ausubel J., Seeyave S., Cato D., Southall B., Weise M., Andrew R., Akamatsu T., Dekeling R., Erbe C., Farmer D., Gentry R., Gross T., Hawkins A., Li F.H., Metcalf K., Miller J.H., Moretti D., 
Rodrigo C. \& Shinke T. 2011. An international quiet ocean experiment. Oceanography 24, 174-181, doi: 10.5670/ oceanog.2011.37.

Brousseau P., De Guise S., Voccia I., Ruby S. \& Fournier M. 2003. Immune status of St. Lawrence Estuary beluga whales. In J.G. Vos et al. (eds.): Toxicology of marine mammals. Pp. 381-403. New York: Taylor and Francis.

Buren A.J., Murphy H.M., Adamack A.T., Davoren G.K., Koen-Alonso M., Montevecchi W.A., Mowbray F.K., Pepin P., Regular P.M., Robert D., Rose G.A., Stenson G.B. \& Varkey D. 2019. The collapse and continued low productivity of a keystone forage fish species. Marine Ecology Progress Series 616, 155-170, doi: 10.3354/meps 12924.

Cairns D.K., Chaput G., Poirier L.A., Avery T.S., Castonguay M., Mathers A., Casselman J.M., Bradford R.G., Pratt T., Verreault G., Clarke K., Veinott G. \& Bernatchez L. 2014. Recovery potential assessment for the American eel (Anguilla rostrata) for eastern Canada: life history, distribution, reported landings, status indicators, and demographic parameters. DFO Canadian Science Advisory Secretariat Research Document 2013/134. Ottawa: Fisheries and Oceans Canada.

Caron L.M.J. \& Smith T.G. 1990. Philopatry and site tenacity of belugas, Delphinapterus leucas, hunted by the Inuit at the Nastapoka Estuary, eastern Hudson Bay. Canadian Bulletin of Fisheries and Aquatic Sciences 224, 69-79.

Casgrain H.R. 1873. La pêche aux marsouins dans le fleuve Saint-Laurent. (Porpoise fishing in the St. Lawrence River.) Montreal: Typographie de l'opinion publique. Accessed on the internet at https://ia802906.us.archive.org/12/items/ cihm_00526/cihm_00526.pdf on 16 June 2021.

Chion C., Lagrois D., Dupras J., Turgeon S., McQuinn I.H., Michaud R., Ménard N. \& Parrott L. 2017. Underwater acoustic impacts of shipping management measures: results from a social-ecological model of boat and whale movements in the St. Lawrence River Estuary (Canada). Ecological Modelling 354, 72-87, doi: 10.1016/j. ecolmodel.2017.03.014.

Chion C., Turgeon S., Michaud R., Landry J.-A. \& Parrott L. 2009. Portrait de la navigation dans le parc marin du SaguenaySaint-Laurent. Caractérisation des activités sans prélèvement de ressources entre le ler mai et le 31 octobre 2007. (Overview of the navigation in the Saguenay-St. Lawrence Marine Park. Characterization of the activities without resource removals between 1 May and 31 October 2007.) Unpublished report for Parcs Canada. Accessed on the internet at https://www.pc.gc.ca/-/ media/amnc-nmca/qc/saguenay/WET4/Publications-scientific/Chion-et-al2009_Portrait-de-la-navigation-dansle-parc-marin-du-Saguenay-Saint-Laurent-2007.pdf on 6 July 2021.

Christiansen F., Bertulli C.G., Rasmussen M.H. \& Lusseau D. 2015. Estimating cumulative exposure of wildlife to non-lethal disturbance using spatially explicit capture recapture models. Journal of Wildlife Management 79, 311-324, doi: 10.1111/conl.12166.

Clark C.W., Ellison W.T., Southall B.L., Hatch L., Van Parijs S.M., Frankel A. \& Ponirakis D. 2009. Acoustic masking in marine ecosystem: intuitions, analysis, and implication. Marine Ecology Progress Series 395, 201-222, doi: 10.3354/ meps08402.
Colbeck G.J., Duchesne P., Postma L.P., Lesage V., Hammill M.O. \& Turgeon J. 2013. Groups of related belugas (Delphinapterus leucas) travel together during their seasonal migrations in and around Hudson Bay. Proceedings of the Royal Society of London B 280, article no. 20122552, doi: 10.1098/ rspb.2012.2552.

COSEWIC 2014. COSEWIC assessment and status report on the Beluga Whale Delphinapterus leucas, St. Lawrence Estuary population, in Canada. Ottawa: Committee on the Status of Endangered Wildlife in Canada.

COSEWIC 2016. Designatable units for beluga whales (Delphinapterus leucas) in Canada. Ottawa: Committee on the Status of Endangered Wildlife in Canada.

Costa L.G., de Laat R., Tagliaferri S. \& Pellacani C. 2014. A mechanistic view of polybrominated diphenyl ether (PBDE) developmental neurotoxicity. Toxicology Letters 230, 282-294, doi: 10.1016/j.toxlet.2013.11.011.

Dawson T.P., Jackson S.T., House J.I., Prentice I.C. \& Mace G.M. 2011 . Beyond predictions: biodiversity conservation in a changing climate. Science 332, 53-58, doi: 10.1126/ science. 1200303.

De Guise S. 1998. Effects of in vitro exposure of beluga whale leukocytes to selected organochlorines. Journal of Toxicology and Environmental Health Part A 55, 479-493, doi: 10.1080/009841098158287.

De Guise S., Lagacé A. \& Béland P. 1994. Tumors in St Lawrence beluga whales (Delphinapterus leucas). Veterinary Pathology 31, 444-449, doi: 10.1177/03009858940 3100406.

De Guise S., Martineau D., Béland P. \& Fournier M. 1995. Possible mechanisms of action of environmental contaminants on St. Lawrence beluga whales (Delphinapterus leucas). Environmental Health Perspective 103, Suppl. 4, 73-77.

de March B.G.E. \& Postma L.D. 2003. Molecular genetic stock discrimination of belugas (Delphinapterus leucas) hunted in Eastern Hudson Bay, Northern Québec, Hudson Strait, and Sanikiluaq (Belcher Islands), Canada, and comparisons to adjacent populations. Arctic 56, 111-124, doi: 10.14430/arctic607.

Dennis R.L.H., Dapporto L., Fattorini S. \& Cook L.M. 2011. The generalism-specialism debate: the role of generalists in the life and death of species. Biological Journal of the Linnean Society London 104, 725-737, doi: 10.1111/j.1095-8312.2011.01789.x.

Desrosiers J. 1994. Analyse photogrammétrique de la structure et la dynamique de la population de bélugas du Saint-Laurent. (Photogrammetric analysis of the structure and dynamics of the St. Lawrence beluga population.) MSc thesis, Laval University.

De Wit C.A. 2002. An overview of brominated flame retardants in the environment. Chemosphere 46, 583-624, doi: 10.1016/s0045-6535(01)00225-9.

DFO 2014. Status of beluga (Delphinapterus leucas) in the St. Lawrence River Estuary. DFO Canadian Science Advisory Secretariat Science Advisory Report 2013/076. Ottawa: Fisheries and Oceans Canada.

DFO 2017. St. Lawrence Estuary beluga. A science-based review of recovery actions for three at-risk whale populations. Accessed on the internet at https://waves-vagues.dfompo.gc.ca/Library/40680253.pdf on 20 April 2021. 
DFO 2020. Action plan to reduce the impact of noise on the beluga whale (Delphinapterus leucas) and other marine mammals at risk in the St. Lawrence Estuary. Ottawa: Fisheries and Oceans Canada.

Diaz R.J. \& Rosenberg R. 2008. Spreading dead zones and consequences for marine ecosystems. Science 321, 926-929, doi: 10.1126/science.1156401.

Dionne S. 2001. Plan de conservation des écosystèmes du parc marin du Saguenay-Saint-Laurent. Parcs Canada, parc marin du Saguenay-Saint-Laurent. (Saguenay-St. Lawrence Marine Park Ecosystem Conservation Plan. Parks Canada, Saguenay-St. Lawrence Marine Park.) Quebec: Parcs Canada.

El-Sabh M.I. \& Silverberg N. 1990. Oceanography of a largescale estuarine system: the St. Lawrence. New York: Springer.

Erbe C., Dunlop R. \& Dolman S. 2018. Effects of noise on marine mammals. In H. Slabbekoorn et al. (eds.): Effects of anthropogenic noise on animals. Pp. 277-309. New York: Springer, doi: 10.1007/978-1-4939-8574-6_10.

Ferchoui B. 2019. Nouvelle approche chimique basée sur la bioaccumulation des retardateurs de flamme pour identifier et évaluer la diète du béluga du Saint-Laurent, Delphinapterus leucas. (New chemical approach based on the bioaccumulation of flame retardants to identify and evaluate the diet of the St. Lawrence beluga, Delphinapterus leucas.) MSc thesis, University du Quebec à Rimouski.

Finley K.J., Miller G.W., Davis R.A. \& Greene C.R. 1990. Reactions of belugas, Delphinapterus leucas, and narwhals, Monodon monoceros, to ice-breaking ships in the Canadian high Arctic. Canadian Bulletin of Fisheries and Aquatic Sciences 224, 97-1 17.

Fréchet A. 1990. Catchability variations of cod in the marginal ice zone. Canadian Journal of Fisheries and Aquatic Sciences 47, 1678-1683.

Galbraith P.S., Chassé J., Caverhill C., Nicot P., Gilbert D., Lefaivre D. \& Lafleur C. 2020. Physical oceanographic conditions in the Gulf of St. Lawrence in 2018. DFO Canadian Science Advisory Secretariat Research Document 2020/030. Ottawa: Fisheries and Oceans Canada.

Gearing J.N., Gearing P.J., Noël M. \& Smith J.N. 1994. Polycyclic aromatic hydrocarbons in sediment of the St. Lawrence Estuary. In R. Coillie et al. (eds): Proceedings of the Twentieth Annual Aquatic Toxicity Workshop, October 17-21, 1993, Quebec City, Quebec. Canadian Technical Report of Fisheries and Aquatic Sciences 1989. Pp. 58-64. Ottawa: Fisheries and Oceans Canada.

Geraci J.R., Anderson, D.M., Timperi, R.J., St. Aubin, D.J., Early, G.A., Prescott, J.H. \& Mayo C.A. 1989. Humpback whales (Megaptera novaeangliae) fatally poisoned by dinoflagellate toxin. Canadian Journal of Fisheries and Aquatic Sciences 46, 1895-1898, doi: 10.1139/f89-238.

Gervaise C., Aulanier F., Roy N. \& Simard Y. 2015. Mapping probability of shipping sound exposure level. Journal of the Acoustical Society of America 137, EL429-435, doi: 10.1121/1.4921673.

Gervaise C., Simard Y., Roy N., Kinda B. \& Ménard N. 2012. Shipping noise in whale habitat: characteristics, sources, budget, and impact on belugas in Saguenay-St. Lawrence Marine Park hub. Journal of the Acoustical Society of America 132, 76-89, doi: 10.1121/1.4728190.
Gilbert D., Sundby B., Gobeil C., Mucci A. \& Tremblay G.-H. 2005. A seventy-two-year record of diminishing deepwater oxygen in the St. Lawrence Estuary: the Northwest Atlantic connection. Limnology and Oceanography 50, 1654-1666, doi: 10.4319/lo.2005.50.5.1654.

Gobeil C., Johnson W.K., MacDonald R.W. \& Wong C.S. 1995. Sources and burden of lead in St. Lawrence Estuary sediments: isotopic evidence. Environmental Science and Technology 29, 193-201.

Gosselin J.-F., Hammill M.O. \& Mosnier A. 2014. Summer abundance indices of St. Lawrence Estuary beluga (Delphinapterus leucas) from a photographic survey in 2009 and 28 line transect surveys from 2001 and 2009. DFO Canadian Science Advisory Secretariat Research Document 2014/021. Ottawa: Fisheries and Oceans Canada.

Gruner E. 1973. Clinical aspects of the nutritional status of the dam and parturition: calving problems and early viability of the calf. Current Topics in Veterinary Medicine and Animal Science 4, 468-477.

Gulland F.M.D. \& Hall A.J. 2007. Is marine mammal health deteriorating? Trends in the global reporting of marine mammal disease. Ecohealth 4, 145-150.

Hammill M.O., den Heyer C.E., Bowen W.D. \& Lang S.L.C. 2017. Grey seal population trends in Canadian waters, 19602016 and harvest advice. DFO Canadian Science Advisory Secretariat Research Document 2017/052. Ottawa: Fisheries and Oceans Canada.

Hammill M.O., Lesage V. \& Kingsley M.C.S. 2003. Cancers in beluga from the St Lawrence Estuary. Environmental Health Perspective 111, A77-A78.

Hammill M.O., Measures L.N., Gosselin J.-F. \& Lesage V. 2007. Lack of recovery in St. Lawrence Estuary beluga. DFO Canadian Science Advisory Secretariat Research Document 2007/026. Ottawa: Fisheries and Oceans Canada.

Hammill M.O., Stenson G.B., Doniol-Valcroze T. \& Mosnier A. 2015. Conservation of Northwest Atlantic harp seals: past success, future uncertainty? Biological Conservation 192, 181-191, doi: 10.1016/j.biocon.2015.09.016.

Harington C.R. 1977. Marine mammals in the Champlain Sea and the Great Lakes. Annals of the New York Academy of Science 288, 508-537, doi: 10.1111/j.1749-6632.1977.tb33640.x.

Harington C.R. 2008. The evolution of Arctic marine mammals. Ecological Applications 18, S23-S40, doi: 10.1890/ 06-0624.1.

Harwood L.A., Kingsley M.C.S. \& Smith T.G. 2014. An emerging pattern of declining growth rates in belugas of the Beaufort Sea: 1989-2008. Arctic 67, 483-492, doi: 10.14430/arctic4423.

Jönsson K.I. 1997. Capital and income breeding as alternative tactics of resource use in reproduction. Oikos 78 , 57-66, doi: 10.2307/3545800.

Kassen R. 2002. The experimental evolution of specialists, generalists and the maintenance of diversity. Journal of Evolutionary Biology 15, 173-190, doi: 10.1046/j.14209101.2002.00377.x.

Kastelein R.A., Ford J., Berghout E., Wiepkema P.R. \& van Boxsel M. 1994. Food consumption, growth and reproduction of belugas (Delphinapterus leucas) in human care. Aquatic Mammals 20, 81-97. 
Kelley T.C., Loseto L.L., Stewart R.E.A., Yurkowski M. \& Ferguson S.H. 2010. Importance of eating capelin: unique dietary habits of Hudson Bay beluga. In S.H. Ferguson et al. (eds.): A little less Arctic-top predators in the world's largest northern inland sea, Hudson Bay. Pp. 53-69. Dordrecht: Springer.

Kingsley M.C.S. 2002. Status of the belugas of the St. Lawrence Estuary, Canada. NAMMCO Scientific Publications 4, 239-257.

Kingsley M.C.S \& Hammill M.O. 1991. Photographic census surveys of the St. Lawrence beluga population, 1988 and 1990. Canadian Technical Report of Fisheries and Aquatic Sciences 1776. Mont-Joli: Fisheries and Oceans Canada.

Kovacs K.M., Lydersen C., Overland J.E. \& Moore S.E. 2011. Impacts of a changing sea-ice conditions on Arctic marine mammals. Marine Biodiversity 41, 181-194, doi: 10.1007/ s12526-010-0061-0.

Laidre K.L., Stirling I., Lowry L.F., Wiig O., Heide-Jørgensen M.-P. \& Ferguson S.H. 2008. Quantifying the sensitivity of Arctic marine mammals to climate-induced habitat change. Ecological Applications 18, Suppl., S97-S125.

Lair S., Gentes M.-L. \& Measures L.N. 2015. Documentation de l'évolution du protocole d'examen des carcasses de béluga de l'estuaire du Saint-Laurent de 1983 à 2012. (Documentation of the evolution of the protocol for the examination of beluga carcasses in the St. Lawrence Estuary from 1983 to 2012.) Rapport Technique Canadien des Sciences Halieutiques et Aquatiques 3143. MontJoli: Fisheries and Oceans Canada.

Lair S., Measures L.N. \& Martineau D. 2016. Pathological findings and trends in mortality in the beluga (Dephinapterus leucas) population of the St. Lawrence Estuary, Québec, Canada, from 1983 to 2012 . Veterinary Pathology 53, 22-36, doi: 10.1177/0300985815604726.

Landsberg J.H. 2002. The effects of harmful algal blooms on aquatic organisms. Reviews in Fisheries Science 10, 113-390, doi: 10.1080/20026491051695.

Lavaud R., Thomas Y., Pecquerie L., Benoît H.P., Guyondet T., Flye-Sainte-Marie J. \& Chabot D. 2019. Modeling the impact of hypoxia on the energy budget of Atlantic cod in two populations of the Gulf of Saint-Lawrence, Canada. Journal of Sea Research 143, 243-253, doi: 10.1016/j.seares.2018.07.001.

Lebeuf M. 2009. La contamination du béluga de l'estuaire du Saint-Laurent par les polluants organiques persistants en revue. (A review of the contamination of the St. Lawrence Estuary beluga by persistent organic pollutants.) Journal of Water Science 22, 199-233, doi: 10.7202/037482ar.

Lebeuf M., Measures L., Noël M., Raach M. \& Trottier S. 2014. A twenty-one year temporal trend of persistent organic pollutants in St. Lawrence Estuary beluga, Canada. Science of the Total Environment 485, 377-386, doi: 10.1016/j. scitotenv.2014.03.097.

Lebeuf M. \& Nunes T. 2005. PCBs and OCPs in sediment cores from the lower St. Lawrence Estuary, Canada: evidence of fluvial inputs and time lag in delivery to coring sites. Environmental Science and Technology 39, 1470-1478, doi: 10.1021/es049051c.

Lebeuf M., Raach M., Measures L., Ménard N. \& Hammill M. 2014. Temporal trends of PBDEs in adult and newborn beluga (Delphinapterus leucas) from the St. Lawrence Estuary.
DFO Canadian Science Advisory Secretariat Research Document 2013/120. Ottawa: Fisheries and Oceans Canada.

Lesage V. 2014. Trends in the trophic ecology of St. Lawrence beluga (Delphinapterus leucas) over the period 1988-2012, based on stable isotope analysis. DFO Canadian Science Advisory Secretariat Research Document 2013/126. Ottawa: Fisheries and Oceans Canada.

Lesage V., Barrette C., Kingsley M.C.S. \& Sjare B. 1999. The effect of vessel noise on the vocal behavior of belugas in the St. Lawrence River Estuary, Canada. Marine Mammal Science 15, 65-84, doi: 10.1111/j.1748-7692.1999. tb00782.x.

Lesage V., Lair S., Turgeon S. \& Béland P. 2020. Diet of St. Lawrence Estuary beluga, Delphinapterus leucas, in a changing ecosystem. Canadian Field-Naturalist 134, 21-35, doi: 10.22621/cfn.v134il.2421.

Lesage V., McQuinn I.H., Carrier D., Gosselin J.-F. \& Mosnier A. 2014. Exposure of the beluga (Delphinapterus leucas) to marine traffic under various scenarios of transit route diversion in the St. Lawrence Estuary. DFO Canadian Science Advisory Secretariat Research Document 2013/125. Ottawa: Fisheries and Oceans Canada.

Lesage V., Measures L., Mosnier A., Lair S. \& Béland P. 2014. Mortality patterns in St. Lawrence Estuary beluga (Delphinapterus leucas), inferred from the carcass recovery data, 1983-2012. DFO Canadian Science Advisory Secretariat Research Document 2013/118. Ottawa: Fisheries and Oceans Canada.

Lockyer C. 1986. Body fat condition in Northeast Atlantic fin whales and its relationship with reproduction and food resources. Canadian Journal of Fisheries and Aquatic Sciences $43,142-147$.

Lusseau D. \& Bejder L. 2007. The long-term consequences of short-term responses of disturbance experiences from whale watching impact assessment. International Journal of Comparative Psychology 20, 228-236, doi: 10.5070/ P4202009991.

Marcoux M., McMeans B.C., Fisk A.T. \& Ferguson S.H. 2012. Composition and temporal variation in the diet of beluga whales, derived from stable isotopes. Marine Ecology Progress Series 471, 283-291, doi: 10.3354/meps 10029.

Martel L.M., Gagnon J., Massé R., Leclerc A. \& Tremblay L. 1986. Polycyclic aromatic hydrocarbons in sediments from the Saguenay Fjord, Canada. Bulletin of Environmental Contamination and Toxicology 37, 133-140.

Martineau D., Béland P., Desjardins C. \& Lagacé A. 1987. Levels of organochlorine chemicals in tissues of beluga whales (Delphinapterus leucas) from the St. Lawrence Estuary, Québec, Canada. Archives of Environmental Contamination and Toxicology 16, 137-147.

Martineau D., De Guise S., Fournier M., Shugart L.R., Girard C., Lagacé A. \& Béland P. 1994. Pathology and toxicology of beluga whales from the St Lawrence Estuary, Quebec, Canada: past, present and future. Science of the Total Environment 154, 201-215, doi: 10.1016/0048-9697(94)90088-4.

Martineau D., Lemberger K., Dallaire A., Labelle P., Lipscomb T.P., Michel P. \& Michaelian I. 2002. Cancer in wildlife, a case study: beluga from the St Lawrence Estuary, Quebec, Canada. Environmental Health Perspective 110, 285-292, doi: 10.1289/ehp.02110285. 
McQuinn I.H., Lesage V., Carrier D., Larrivée G., Samson Y., Chartrand S., Michaud R. \& Theriault J. 2011. A threatened beluga (Delphinapterus leucas) population in the traffic lane: vessel-generated noise characteristics of the Saguenay-St. Lawrence Marine Park, Canada. Journal of the Acoustical Society of America 130, 3661-3673, doi: $10.1121 / 1.3658449$.

Mee J.F. 2008. Prevalence and risk factors for dystocia in dairy cattle: a review. Veterinary Journal 176, 93-101, doi: 10.1016/j.tvjl.2007.12.032.

Ménard N.R., Michaud R., Chion C. \& Turgeon S. 2014. Documentation of maritime traffic and navigational interactions with St. Lawrence Estuary beluga (Delphinaterus leucas) in calving areas between 2003 and 2012. DFO Canadian Science Advisory Secretariat Research Document 2014/003. Ottawa: Fisheries and Oceans Canada.

Michaud R. 1993. Distribution estivale du béluga du StLaurent; synthèse 1986-1992. (Summer distribution of the St. Lawrence beluga; synthesis 1986-1992.) Canadian Technical Report of Fisheries and Aquatic Sciences 1906. Quebec: Fisheries and Oceans Canada.

Michaud R. 2014. St. Lawrence Estuary beluga (Delphinapterus leucas) population parameters based photo-identification surveys, 1989-2012. DFO Canadian Science Advisory Secretariat Research Document 2013/130. Ottawa: Fisheries and Oceans Canada.

Miller C.A., Reeb D., Best P.B., Knowlton A., Brown M.W. \& Moore M.J. 2011. Blubber thickness in right whales Eubalaena glacialis and Eubalaena australis related to reproduction, life history status and prey abundance. Marine Ecology Progress Series 438, 267-283, doi: 10.3354/meps09174.

Mosnier A., Doniol-Valcroze T., Gosselin J.-F., Lesage V., Measures L.N. \& Hammill M.O. 2015. Insights into processes of population decline using an integrated population model: the case of the St. Lawrence beluga (Delphinapterus leucas). Ecological Modelling 314, 15-31, doi: 10.1016/j. ecolmodel.2015.07.006.

Mosnier A., Larocque R., Lebeuf M., Gosselin J.-F., Dubé S., Lapointe V., Lesage V., Lefaivre D., Senneville S. \& Chion C. 2016. Définition et caractérisation de l'habitat du béluga (Delphinapterus leucas) de l'estuaire du Saint-Laurent selon une approche écosystémique. (Definition and characterization of the habitat of the beluga (Delphinapterus leucas) of the St. Lawrence Estuary using an ecosystem approach.) Secrétariat canadien de consultation scientifique du MPO, Document de Recherche 2016/052. Ottawa: Fisheries and Oceans Canada.

Mosnier A., Lesage V., Gosselin J.-F., Lemieux Lefebvre S., Hammill M.O. \& Doniol-Valcroze T. 2010. Information relevant to the documentation of habitat use by St. Lawrence beluga (Delphinapterus leucas), and quantification of habitat quality. DFO Canadian Science Advisory Secretariat Research Document 2009/098. Mont-Joli: Fisheries and Oceans Canada.

Muir D.C.G., Ford C.A., Stewart R.E.A., Smith T.G., Addison R.F., Zinck M.T. \& Béland P. 1990. Organochlorine contaminants in beluga (Delphinapterus leucas) from Canadian waters. Canadian Bulletin of Fisheries and Aquatic Sciences 224, 165-190.

Muir D.C.G., Koczanski K., Rosenberg B. \& Béland P. 1996. Persistent organochlorines in beluga whales (Delphinapterus leucas) from the St Lawrence River Estuary. II.
Temporal trends 1982-1994. Environmental Pollution 93, 235-245.

O'Corry-Crowe G. 2008. Climate change and the molecular ecology of Arctic marine mammals. Ecological Applications 18, Suppl., S56-S76.

O'Corry-Crowe G., Mahoney A.R., Suydam R., Quakenbush L., Whiting A., Lowry L. \& Harwood L. 2016. Genetic profiling links changing sea-ice to shifting beluga whale migration patterns. Biology Letters 12, 20160404, doi: 10.1098/ rsbl.2016.0404.

O'Corry-Crowe G., Suydam R., Quakenbush L., Potgieter B., Harwood L., Litovka D., Ferrer T., Citta J., Burkanov V., Frost K. \& Mahoney B. 2018. Migratory culture, population structure and stock identity in North Pacific beluga whales (Delphinapterus leucas). PLoS One 13, e0194201, doi: 10.1371/journal.pone.0194201.

O'Corry-Crowe G., Suydam R., Quakenbush L., Smith T.G., Lydersen C., Kovacs K.M., Orr J., Harwood L., Litovka D. \& Ferrer T. 2020. Group structure and kinship in beluga whale societies. Scientific Reports 10, article no. 11462, doi: 10.1038/s41598-020-67314-W.

Ofori B.Y., Stow A.J., Baumgartner J.B. \& Beaumont L.J. 2017. Influence of adaptive capacity on the outcome of climate change vulnerability assessment. Scientific Reports 7, article no. 12979, doi: 10.1038/s41598-017-13245-y.

Patenaude N.J., Quinn J.S., Béland P., Kingsley M. \& White B.N. 1994. Genetic variation of the St. Lawrence beluga whale population assessed by DNA fingerprinting. Molecular Ecology 3, 375-381, 10.1111/j.1365-294x.1994. tb00077.x.

Pippard L. 1985. Status of the St. Lawrence River population of beluga, Delphinapterus leucas. Canadian Field-Naturalist 99, 438-450.

Pirotta E., Merchant N.D., Thompson P.M., Barton T.R. \& Lusseau D. 2015. Quantifying the effect of boat disturbance on bottlenose dolphin foraging activity. Biological Conservation 181, 82-89, doi: 10.1016/j.biocon.2014.11.003.

Plourde S., Galbraith P., Lesage V., Grégoire F., Bourdgages H., Gosselin J.-F., McQuinn I. \& Scarratt M. 2014. Ecosystem perspective on changes and anomalies in the Gulf of St. Lawrence: a context in support of the management of the St. Lawrence beluga whale population. DFO Canadian Science Advisory Secretariat Research Document 2013/129. Ottawa: Fisheries and Oceans Canada.

Plourde S., Grégoire F., Lehoux C., Galbraith P.S., Castonguay M. \& Ringuette M. 2014. Effect of environmental variability on body condition and recruitment success of Atlantic Mackerel (Scomber scombrus L.) in the Gulf of St. Lawrence. Fisheries Oceanography 24, 347-363, doi: 10.1111/ fog. 12113.

Poirier M.C., Lair S., Michaud R., Hernandez-Ramon E.E., Divi K.V., Dwyer J.E., Ester C.D., Si N.N., Ali M., Loseto L.L., Raverty S.A., St. Leger J.A., Van Bonn W.G., Colegrove K., Burek-Huntington K.A., Suydam R., Stimmelmayr R., Pierce Wise J. Sr., Wise S.S., Beauchamp G. \& Martineau D. 2019. Intestinal polycyclic aromatic hydrocarbon-DNA adducts in a population of beluga whales with high levels of gastrointestinal cancers. Environmental Molecular Mutagenesis 60, 29-41, doi: 10.1002/em.22251. 
Postma L.D. 2017. Genetic diversity, population structure and phylogeography among belugas (Delphinapterus leucas) in Canadian waters: broad to fine-scale approaches to inform conservation and management strategies. PhD thesis, University of Manitoba.

Reeves R.R. \& Mitchell E. 1984. Catch history and initial population of white whales (Delphinapterus leucas) in the river and Gulf of St. Lawrence, eastern Canada. Canadian Field-Naturalist 111, 63-121.

Roy N. \& Simard Y. 2015. Bruit ambiant et fréquentation de la région de Cacouna par le béluga du Saint-Laurent à l'été 2014 par monitorage acoustique continu. (Ambient noise and use of the Cacouna region by St. Lawrence beluga in summer 2014 by continuous acoustic monitoring.) Rapport Technique Canadien des Sciences Halieutiques et Aquatiques 3141. Mont-Joli: Fisheries and Oceans Canada.

Ruest B., Neumeier U., Dumont D., Bismuth E., Senneville S. \& Caveen J. 2016. Recent wave climate and expected future changes in the seasonally ice-infested waters of the Gulf of St. Lawrence, Canada. Climate Dynamics 46, 449466, doi: 10.1007/s00382-015-2592-3.

Rugh D.J., Shelden K.E.W. \& Hobbs R.C. 2010. Range contraction in a beluga population. Endangered Species Research 12, 69-75, doi: 10.3354/esr00293.

Savenkoff, C., Castonguay, M., Chabot, D., Hammill, M.O., Bourdages, H. \& Morissette, L. 2007. Changes in the northern Gulf of St. Lawrence ecosystem estimated by inverse modelling: evidence of a fishery-induced regime shift? Estuarine, Coastal and Shelf Science 73, 711-724, doi: 10.1016/j.ecss.2007.03.011.

Scarratt M., Michaud S., Measures L. \& Starr M. 2014. Phytotoxin analyses in St. Lawrence Estuary beluga. DFO Canadian Science Advisory Secretariat Research Document 2013/124. Ottawa: Fisheries and Oceans Canada.

Scheifele P.M., Andrew S., Cooper R.A., Darre M., Musiek F.E. \& Max L. 2005. Indication of a Lombard vocal response in the St. Lawrence River beluga. Journal of the Acoustical Society of America 117, 1486-1492, doi: 10.1121/1.1835508.

Senigaglia V., Christiensen F., Bejder L., Gendron D., Lundquist D., Noren D.P., Schaffar A., Smith J.C., Williams R., Martinez E., Stockin K. \& Lusseau D. 2016. Meta-analyses of whale-watching impact studies: comparisons of cetacean responses to disturbance. Marine Ecology Progress Series 542, 251-263, doi: 10.3354/meps 11497.

Sergeant D.E. 1986. Present status of white whales Delphinapterus leucas in the St. Lawrence Estuary. Naturaliste Canadien 113, 61-81.

Simard Y., Lepage R. \& Gervaise C. 2010. Anthropogenic sound exposure of marine mammals from seaways: estimates for lower St. Lawrence Seaway, eastern Canada. Applied Acoustics 71, 1093-1098, doi: 10.1016/j.apacoust. 2010.05.012.

Simard Y., Roy N., Giard S. \& Yayla M. 2014. Canadian yearround shipping traffic atlas for 2013: volume 1, East Coast marine waters. Canadian Technical Report of Fisheries and Aquatic Sciences 3091 (Vol. 1) E. Mont-Joli: Fisheries and Oceans Canada.

Simond A.E., Houde M., Lesage V., Michaud R., Zbinden D. \& Verreault J. 2019. Associations between organohalogen contaminant and thyroid- and steroid-related gene responses in St. Lawrence Estuary beluga and minke whales. Marine Pollution Bulletin 145, 174-184, doi: 10.1016/j.marpolbul.2019.05.029.

Simond A.E., Houde M., Lesage V. \& Verreault J. 2017. Temporal trends of PBDEs and emerging flame retardants in belugas from the St. Lawrence Estuary (Canada) and comparisons with minke whales and belugas from the Canadian Arctic. Environmental Research 156, 494-504, doi: 10.1016/j.envres.2017.03.058.

Skovring I., Castruita J.A.S., Madsen T.M., Postma L. \& Lorenzen E.D. 2019. Patterns of mtDNA variation in relation to currently recognized stocks of beluga whales, Delphinapterus leucas. Marine Fisheries Review 81, 87-97, doi: 10.7755/MFR.81.3-4.4.

Smetacek V. \& Nicol S. 2005. Polar ocean ecosystems in a changing world. Nature 437, 362-368, doi: 10.1038/nature04161.

Starr M., Lair S., Michaud S., Scarratt M., Quilliam M., Lefaivre D., Robert M., Wotherspoon A., Michaud R., Ménard N., Sauvé G., Lessard S. \& Measures L. 2017. Multispecies mass mortality of marine fauna linked to a toxic dinoflagellate bloom. PLoS One 12, e0176299, doi: 10.1371/ journal.pone.0176299.

Stewart B.E. \& Stewart R.E.A. 1989. Delphinapterus leucas. Mammal Species 336, 1-8, doi: 10.2307/3504210.

Theriault G., Gibbs G. \& Tremblay C. 2002. Cancer in belugas of the St. Lawrence Estuary. Environmental Health Perspectives 110, A562.

Truchon M.-H., Measures L., L'Hérault V., Brethes J.-C., Galbraith P.S., Harvey M., Lessard S., Starr M. \& Lecomte N. 2013. Marine mammal strandings and environmental changes: a 15-year study in the St. Lawrence ecosystem. PLoS One 8, e59311, doi: 10.1371/journal.pone.0059311.

Turgeon J., Duchesne P., Colbeck G.J., Postma L.D. \& Hammill M.O. 2012. Spatiotemporal segregation among summer stocks of beluga (Delphinapterus leucas) despite nuclear gene flow: implication for the endangered belugas in eastern Hudson Bay (Canada). Conservation Genetics 13, 419433, doi: 10.1007/s10592-011-0294-x.

Tyack P.L. \& Clark C.W. 2000. Communication and acoustic behavior of dolphins and whales. In W.W.W. Au \& R.R. Fay (eds.): Hearing by whales and dolphins. Pp. 156-224. New York, NY: Springer.

Valenzuela L., Sironi M., Rowntree V. \& Seger J. 2009. Isotopic and genetic evidence for culturally inherited site fidelity to feeding grounds in southern right whales (Eubalaena australis). Molecular Ecology 18, 782-791, doi: 10.1111/ j.1365-294X.2008.04069.x.

Vergara V., Wood J., Lesage V., Ames A., Mikus M.-A. \& Michaud R. 2021. Can you hear me? Impacts of underwater noise on communication space of adult, sub-adult and calf contact calls of endangered St. Lawrence belugas (Delphinapterus leucas). Polar Research 40, article no. 5521, doi: 10.33265/polar.v40.5521.

Viglino L., Pelletier É. \& St-Louis R. 2004. Highly persistent butyltins in northern marine sediments: a long-term threat for the Saguenay Fjord (Canada). Environmental Toxicology and Chemistry 23, 2673-2681, doi: 10.1897/03-674.

Villanger G.D., Lydersen C., Kovacs K.M., Lie E., Skaare J.U. \& Jenssen B.M. 2011 . Disruptive effects of persistent 
organohalogen contaminants on thyroid function in white whales (Delphinapterus leucas) from Svalbard. Science of the Total Environment 409, 2511-2524, doi: 10.1016/j. scitotenv.2011.03.014.

Vladykov V.D. 1944. Études sur les mammifêres aquatiques. III. Chasse, biologie et valeur économique du marsouin blanc ou béluga (Delphinapterus leucas) du fleuve et $d u$ golfe $d u$ Saint-Laurent. (Studies of aquatic mammals. III. Hunting, biology and economic value of the white whale or beluga [Delphinapterus leucas] of the St. Lawrence River and Gulf.) Quebec: Département des Pêcheries.

Vladykov V.D. 1946. Études sur les mammifêres aquatiques. IV. Nourriture du marsouin blanc (Delphinapterus leucas) du fleuve Saint-Laurent. (Studies of aquatic mammals. IV. Food of the white whale [Delphinapterus leucas] of the St. Lawrence River.) Quebec: Département des Pêcheries.

Wade P.R., Reeves R.R. \& Mesnick S.L. 2012. Social and behavioural factors in cetacean responses to overexploitation: are odontocetes less "resilient" than mysticetes? Journal of Marine Biology 2012(2), article no. 567276, doi: 10.1155/2012/567276.

Wagemann R., Stewart R.E.A., Béland P. \& Desjardins C. 1990. Heavy metals and selenium in tissues of beluga whales, Delphinapterus leucas, from the Canadian Arctic and the St. Lawrence Estuary. Canadian Bulletin of Fisheries and Aquatic Sciences 224, 191-206.

Wassmann P., Duarte C.M., Agustı S. \& Sejr M.K. 2011 . Footprints of climate change in the Arctic marine ecosystem.
Global Change in Biology 17, 1235-1249, doi: 10.1111/ j.1365-2486.2010.02311.x.

Williams R., Lacy R.C., Ashe E., Hall A., Lehoux C., Lesage V., McQuinn I. \& Plourde S. 2017. Predicting responses of St. Lawrence beluga to environmental changes and anthropogenic threats to orient effective management actions. DFO Canadian Science Advisory Secretariat Research Document 2017/027. Ottawa: Fisheries and Oceans Canada.

Williams R. \& Noren D.P. 2009. Swimming speed, respiration rate, and estimated cost of transport in adult killer whales. Marine Mammal Science 25, 327-335, doi: 10.1111/j.1748-7692.2008.00255.x.

Williams R., Wright A.J., Ashe E., Blight L.K., Bruintjes R., Canessa R., Clark C.W., Cullis-Suzuki S., Dakin D.T., Erbe C., Hammond P.S., Merchant N.D., O'Hara P.D., Purser J., Radford A.N., Simpson S.D., Thomas L. \& Wale M.A. 2015. Impacts of anthropogenic noise on marine life: publication patterns, new discoveries, and future directions in research and management. Ocean $\theta$ Coastal Management 115, 17-24, doi: 10.1016/j.ocecoaman.2015.05.021.

Worm B. \& Myers R.A. 2003. Meta-analysis of cod-shrimp interactions reveals top-down control in oceanic food webs. Ecology 84, 162-173, doi: 10.1890/0012-9658(2003) 084[0162:maocsi]2.0.co;2.

Yu L., Han Z. \& Liu C. 2015. A review on the effects of PBDEs on thyroid and reproduction systems in fish. General and Comparative Endocrinology 219, 64-73, doi: 10.1016/j.ygcen. 2014.12.010. 